\title{
Nutrient and heavy metal contents compared among five mushrooms from Pakistan
}

\author{
MUHAMMAD WAHID, ABDUS SATTAR and AFTAB IQBAL
}

\begin{abstract}
WAHID, M., SATTAR, A. \& IQBAL, A. 1992: Nutrient and heavy metal contents compared among five mushrooms from Pakistan. - Karstenia 32:1-5.

The edible mushroom species Agaricus campestris, Morchella esculenta, Morchella conica, Pleurotus ostreatus and Volvariella volvacea were analysed for proximate composition, energy, amino acids and heavy metals. The results indicated wide variation in protein (19.44-36.60\%), fats (1.20-2.60\%), fibre (13.14-17.60\%), ash (8.00-15.93\%) and carbohydrate $(31.73-50.70 \%)$. The coefficient of variation was highest for $\mathrm{Pb}$ and $\mathrm{Mn}$, intermediate for $\mathrm{Cd}, \mathrm{Cu}$ and $\mathrm{Fe}$, and least for $\mathrm{Zn}$. Marked variation was also observed for essential and non-essential amino acids.
\end{abstract}

Key words: Amino acids, cultivated and wild mushrooms, heavy metals, potential nutrients

Muhammed Wahid \& Abdus Sattar, Nuclear Institute for Food and Agriculture (NIFA), Peshawar, Pakistan

Aftab Iqbal, Biology Department, Quaid-e-Azam University, Islamabad, Pakistan

Mushrooms contain a high percentage of all the basic food constituents. They are also a good source of all essential amino acids and have a range of physiologically active substances (Genders 1969). Edible mushrooms are cultivated world-wide under various climatic conditions, depending upon the prevalent culinary customs and trade interests. Their total annual production in the world is well over 1.2 million tons. However, although mushrooms are grown on a commercial scale in several countries, little effort has been made to cultivate them in Pakistan, which has a variety of climatic zones and an abundance of manpower and agro-waste resources (Zafar 1986). Apart from utilizing agro-waste, mushroom cultivation offers new job opportunities, enhances the national food supply and generates foreign exchanges. The nutritional and fuel value of some edible mushrooms have been described earlier by many workers (Genders 1969, Kreula et al. 1976, Zakhary et al. 1983, 1984), and Fritsche (1978) has reported on the conditions for optimum growth and the biology of edible mushrooms. The aim of the present studies was to compare the nutritive value of fungi growing under tropical conditions.

\section{Material and methods}

The species studied were: Agaricus campestris, Morchella esculenta, Morchella conica, Pleurotus ostreatus and Volvariella volvacea. Samples of M. esculenta and $M$. conica were obtained from the Swat Valley of the North Western Province of Pakistan. A. campestris was collected from localities in the Peshawar valley, while $P$. ostreatus and $V$. volvacea were grown at our institute. The spawn of these mushrooms was obtained from the National Agricultural Research Council, Islamabad. Three samples of each species were analysed for various constituents. The proximate composition of oven-dried samples was determined according to the AOAC (1984) methods. Moisture was determined in a drying oven at $105^{\circ} \mathrm{C}$. The samples were analysed for fat by Soxhlet extraction, using petroleum ether (b.p. $40-60^{\circ} \mathrm{C}$ ) in a Soxtec system $\mathrm{H}$ (Tecator), and for protein (\% $\mathrm{N} \times 6.25)$ by the microKjeldahl method. Ash was determined by hieating at $550^{\circ} \mathrm{C}$ and fibre by treating with acid and alkali, using the Fibertec system-M (Tecator). The food energy was calculated from the proximate analysis data by multiplying the $g$ fat by 9 and $g$ protein and 
carbohydrates by 4 . The fat-extracted samples were air-dried for 4 hours and then hydrolysed with $6 \mathrm{~N}$ $\mathrm{HCl}$ for 24 hours in glass tubes, sealed under vacuum. The procedure of Blackburn (1968) was followed for the determination of amino acids, using an Amino Acid Analyser LKB Model 4101.

For heavy metal assays, wet digestion of the samples was performed by the method of O'Dell et al. (1972) modified for macro levels (Sattar \& Chaudry 1978). Simultaneous determination of cadmium, copper, lead and zinc was carried out in the acid digest by the potentiometric stripping techniques (Danielsson et al. 1981), using the Tecator Striptec system, comprising a glass carbon electrode, saturated calomel electrode (SCE) and platinum wire as counter electrode. The stripping curves were measured at a potential of -1.1 volt vs SCE and 180 -second plating time. The concentration of the metals in the samples was evaluated by means of the standard addition techniques, the 1-min. pre-electrolysis/stripping cycle being repeated after each addition. In comparison to calibration curves, the standard addition method is considered to be especially appropriate when the samples are of varying type and origin. In most experiments, two standard additions were used and the concentration of the standard addition solution was so chosen that the first addition almost doubled the concentration of the element. The stripping time for the element was prolonged in proportion to the added amount. The content in the acid digest and finally the sample was then determined by simple calculations. The assays for manganese and iron were made by atomic absorption spectrophotometry, using a Hitachi model 170-10 atomic absorption spectrophotometer.

The results of the various analyses were examined statistically by determining the means, standard deviations and coefficient of variability. The statistical significance was also measured by the analysis of variance and means were separated by the Dancon Multiple Range Test (Little \& Hills 1972).

\section{Results and discussion}

The moisture content of the different mushrooms had a range of $90.4-91.8 \%$. The proximate analysis data (Table 1) indicated that, on a dry matter basis, the $A$. campestris samples had higher protein contents than the other mushroom species. The lowest protein content was observed in $P$. ostreatus. The higher protein levels in A. campestris, M. esculenta and $M$. conica than in the other mushrooms are of special interest in view of the protein shortages of the growing world population. The fat and ash contents were also highest in A. campestris and lowest in P. ostreatus. The statistical analysis of the data on the proximate composition indicated that the mushroom species generally

Table 1. Basic composition of mushrooms. ${ }^{1}$

\begin{tabular}{lcccccc}
\hline Mushrooms & $\begin{array}{c}\text { Protein } \\
\%\end{array}$ & $\begin{array}{c}\text { Fat } \\
\%\end{array}$ & $\begin{array}{c}\text { Ash } \\
\%\end{array}$ & $\begin{array}{c}\text { Fibre } \\
\%\end{array}$ & $\begin{array}{c}\text { Carbohydrates } \\
\%\end{array}$ & $\begin{array}{c}\text { Energy } \\
\text { KCal/100 g }\end{array}$ \\
\hline 1. Agaricus campestris & $36.60^{\mathrm{A}}$ & $2.60^{\mathrm{A}}$ & $15.93^{\mathrm{A}}$ & $13.14^{\mathrm{D}}$ & $31.73^{\mathrm{B}}$ & $296^{\mathrm{B}}$ \\
& $( \pm 0.57)$ & $( \pm 0.23)$ & $( \pm 1.13)$ & $( \pm 0.20)$ & $( \pm 1.12)$ & $( \pm 12)$ \\
2. Morchella esculenta & $32.73^{\mathrm{B}}$ & $2.00^{\mathrm{B}}$ & $9.72^{\mathrm{D}}$ & $17.60^{\mathrm{A}}$ & $37.95^{\mathrm{B}}$ & $300^{\mathrm{AB}}$ \\
& $( \pm 0.33)$ & $( \pm 0.04)$ & $( \pm 1.18)$ & $( \pm 0.47)$ & $( \pm 0.98)$ & $( \pm 14)$ \\
3. Morchella conica & $32.06^{\mathrm{B}}$ & $1.92^{\mathrm{B}}$ & $10.12^{\mathrm{C}}$ & $17.20^{\mathrm{A}}$ & $39.70^{\mathrm{B}}$ & $304^{\mathrm{AB}}$ \\
& $( \pm 1.16)$ & $( \pm 0.03)$ & $( \pm 1.24)$ & $( \pm 1.14)$ & $( \pm 1.57)$ & $( \pm 11)$ \\
4. Pleurotus ostreatus & $19.44^{\mathrm{C}}$ & $1.20^{\mathrm{C}}$ & $8.00^{\mathrm{B}}$ & $14.33^{\mathrm{C}}$ & $57.03^{\mathrm{A}}$ & $312^{\mathrm{A}}$ \\
& $( \pm 1.41)$ & $( \pm 0.30)$ & $( \pm 1.04)$ & $( \pm 0.33)$ & $( \pm 1.38)$ & $( \pm 8)$ \\
5. Voluariella volvacea & $31.62^{\mathrm{B}}$ & $1.32^{\mathrm{C}}$ & $11.84^{\mathrm{B}}$ & $15.60^{\mathrm{B}}$ & $39.43^{\mathrm{B}}$ & $297^{\mathrm{B}}$ \\
& $( \pm 2.54)$ & $( \pm 0.02)$ & $( \pm 1.40)$ & $( \pm 0.16)$ & $( \pm 2.06)$ & $( \pm 15)$ \\
CV & 21.27 & 31.34 & 27.10 & 12.11 & 22.92 & 2.66 \\
LSD 5\% & 1.32 & 0.38 & 0.37 & 0.79 & 17.49 & 13.00
\end{tabular}

1. On a moisture-free basis. The values are the average of three determinations $(n=3)$ and those in parenthesis represent the standard deviation.

$\mathrm{CV}=$ Coefficient of variability (sample standard deviation expressed as a percentage of the mean). 
differed significantly in their contents of these nutrients $(\mathrm{P}<0.05)$. Kreula et al. $(1978)$ reported values which ranged from 12 to $35 \%$ for protein and 2 to $9 \%$ for fat contents in 15 different species of mushrooms. The crude fibre content of $V$. volvacea found in our study is in agreement with those given by Bano et al. (1962) and Zakhary et al. (1984). Souci et al. (1969) reported ranges of $5.2-11.2 \%$ and $13.39 \%$, respectively, for crude and dietary fibre contents in certain mushroom species. FAO (1972) gave higher values for the fat contents and lower values for crude fibre than those recorded by us for $V$. volvacea. Zakhary et al. (1983) obtained a range of $34.0-40.6 \%$ for carbohydrates in various species of mushrooms. The energy value calculated for different mushrooms ranged from 291 to $312 \mathrm{kCal} / 100 \mathrm{~g}$ of dry matter. However, Genders (1969) reported the fuel value of mushrooms as $210 \mathrm{kCal} / 100 \mathrm{~g}$. The low caloric value of mushrooms is due to their low fat and carbohydrate contents. It has, therefore, been considered virtually impossible for anyone to gain weight by eating mushrooms alone (Stanton 1984).

The data on heavy and trace elements are presented in Table 2. M. conica had the highest concentration $(\mathrm{P}<0.05)$ of cadmium and zinc, whereas the values for copper, lead and manganese were highest $(\mathrm{P}<0.05)$ in $M$. esculenta. The highest iron $(\mathrm{Fe})$ contents were recorded for $V$. volvacea and the lowest for M. esculenta. The Mn content of the five analysed mushrooms ranged from 4.5 to $32.6 \mu \mathrm{g} / \mathrm{g}$. The statis- tical analysis of the data on heavy and trace metals of mushrooms indicated that these metals generally differed significantly $(\mathrm{P}<0.05)$ among the species. The $\mathrm{Cu}$ content ranged from 10.0 to $45.8 \mu \mathrm{g} / \mathrm{g}$ in our analysed samples. The values given for $\mathrm{Cu}$ in the literature have been $22-85 \mathrm{mg} / \mathrm{kg}$ (Kreula et al. 1978) and 0.3-29 mg/100 g (Hinneri 1975). The Zn content in our mushroom species was $43.5-64.8 \mu \mathrm{g} / \mathrm{g}$. The highest content reported for $\mathrm{Zn}$ by Hinneri (1975) was $120 \mathrm{mg} / 100 \mathrm{~g}$ with lower values of $50 \mathrm{mg} / 100 \mathrm{~g}$. Egyptian mushrooms (Agaricus and Collybia spp.) contained $17.8-42.9 \mathrm{mg} / 100 \mathrm{~g}$ of Fe and $0.12-0.47$ $\mathrm{mg} / 100 \mathrm{~g}$ of Mn (Zakhary et al. 1983). Kreula et al. (1976) reported values of $24-277 \mathrm{mg} / 100 \mathrm{~g}$ for $\mathrm{Mn}$ in different mushroom species. Hinneri (1975) also observed considerable variation in the $\mathrm{Fe}$ contents of various mushroom viz. $3.4-140 \mathrm{mg} / 100 \mathrm{~g}$. There may be few references on the $\mathrm{Cd}$ and $\mathrm{Pb}$ contents of mushrooms, but the permissible levels of heavy metals have been given. According to the Food and Nutrition Board (1974), the average daily requirement of $\mathrm{Zn}$ is $15 \mathrm{mg}$ and that of copper is $1 \mathrm{mg}$. The Joint FAO/ WHO Expert Committee (1972) set up the tolerable weekly intake limits for $\mathrm{Cd}$ and $\mathrm{Pb}$ as 3.15 and $3 \mathrm{mg}$, respectively. The maximum limits for $\mathrm{Cd}$ and $\mathrm{Pb}$ in different types of foods were given as 6.0 and $20.0 \mathrm{mg}$ $\mathrm{kg}^{-1}$, respectively, in Pakistan (Govt. of Pak. 1979).

The amino acid composition of the mushroom species was determined and the results are presented in Table 3 . The analysed samples contained 17 amino

Table 2. Heavy and trace metal contents of mushrooms $(\mu \mathrm{g} / \mathrm{g}) .^{1}$

\begin{tabular}{lcccccc}
\hline Mushrooms & Cadmium & Copper & Lead & Zinc & Iron & Manganese \\
\hline 1. Agaricus campestris & $3.2^{\mathrm{B}}$ & $13.0^{\mathrm{D}}$ & $3.2^{\mathrm{B}}$ & $50.7^{\mathrm{c}}$ & $158.0^{\mathrm{C}}$ & $22.4^{\mathrm{C}}$ \\
& $\left( \pm 0.4^{\mathrm{C}}\right)$ & $( \pm 0.19)$ & $( \pm 0.28)$ & $( \pm 6.28)$ & $( \pm 11.27)$ & $( \pm 0.57)$ \\
2. Morchella esculenta & $1.9^{\mathrm{D}}$ & $45.8^{\mathrm{A}}$ & $4.5^{\mathrm{A}}$ & $56.8^{\mathrm{B}}$ & $98.9^{\mathrm{B}}$ & $32.6^{\mathrm{A}}$ \\
& $( \pm 0.14)$ & $( \pm 2.28)$ & $( \pm 0.14)$ & $( \pm 9.28)$ & $( \pm 10.85)$ & $( \pm 0.85)$ \\
3. Morchella conica & $4.4^{\mathrm{A}}$ & $37.2^{\mathrm{B}}$ & $2.8^{\mathrm{B}}$ & $62.8^{\mathrm{A}}$ & $167.3^{\mathrm{B}}$ & $21.7^{\mathrm{B}}$ \\
& $( \pm 0.26)$ & $( \pm 2.57)$ & $( \pm 0.42)$ & $( \pm 3.96)$ & $( \pm 21.84)$ & $( \pm 0.85)$ \\
4. Pleurotus ostreatus & $2.2^{\mathrm{CD}}$ & $25.5^{\mathrm{C}}$ & $0.3^{\mathrm{C}}$ & $43.5^{\mathrm{B}}$ & $110.8^{\mathrm{D}}$ & $9.3^{\mathrm{D}}$ \\
& $( \pm 0.21)$ & $( \pm 1.51)$ & $( \pm 0.14)$ & $( \pm 2.71)$ & $( \pm 12.40)$ & $( \pm 0.57)$ \\
5. Voluariella volvacea & $2.7^{\mathrm{BC}}$ & $10.0^{\mathrm{B}}$ & $0.4^{\mathrm{C}}$ & $46.8^{\mathrm{D}}$ & $240.0^{\mathrm{A}}$ & $4.5^{\mathrm{B}}$ \\
& $( \pm 0.23)$ & $( \pm 0.14)$ & $( \pm 0.14)$ & $( \pm 3.85)$ & $( \pm 22.26)$ & $( \pm 0.59)$ \\
CV & 34.1 & 46.9 & 82.0 & 16.1 & 36.0 & 62.0 \\
LSD 5\% & 0.59 & 1.21 & 0.76 & 2.26 & 11.82 & 0.43 \\
\hline
\end{tabular}

1. On a moisture-free basis. The values are the average of three determinations $(n=3)$ and those in parenthesis represent the standard deviation.

$\mathrm{CV}=$ Coefficient of variability (sample standard deviation expressed as a percentage of the mean). 
Table 3. Amino acid composition of mushrooms (g/100 g). ${ }^{1}$

\begin{tabular}{lcccccc}
\hline Amino acids & A.campestris & M. esculenta & M. conica & P. ostreatus & V. volvacea & CV \\
\hline Aspartic acid & 2.46 & 1.95 & 1.72 & 1.17 & 1.00 & 35.68 \\
Threonine & 1.25 & 1.17 & 1.07 & 0.69 & 0.85 & 23.03 \\
Serine & 1.46 & 1.08 & 1.04 & 1.39 & 0.68 & 27.62 \\
Glutamic acid & 3.08 & 2.76 & 2.98 & 2.62 & 1.56 & 23.41 \\
Proline & 1.11 & 0.85 & 0.80 & 0.41 & 0.23 & 52.18 \\
Glycine & 0.83 & 0.81 & 0.80 & 0.54 & 0.67 & 16.92 \\
Alanine & 1.04 & 1.03 & 1.30 & 0.90 & 0.95 & 14.79 \\
Cystine & 0.02 & 0.04 & 0.03 & 0.02 & 0.02 & 34.40 \\
Valine & 1.01 & 0.90 & 0.97 & 0.59 & 0.17 & 48.47 \\
Methionine & 0.22 & 1.99 & 1.43 & 0.34 & 0.65 & 81.96 \\
Isoleucine & 1.64 & 2.74 & 2.52 & 1.40 & 0.75 & 45.30 \\
Leucine & 0.55 & 2.60 & 2.31 & 1.62 & 0.56 & 62.62 \\
Tyrosine & 0.37 & 0.46 & 0.60 & 0.57 & 0.27 & 30.31 \\
Phenylalanine & 0.76 & 1.02 & 0.82 & 0.89 & 0.54 & 22.01 \\
Histidine & 1.33 & 0.66 & 0.66 & 0.55 & 0.42 & 48.74 \\
Lysine & 2.03 & 1.46 & 1.48 & 1.22 & 0.85 & 30.58 \\
Arginine & 0.71 & 2.53 & 2.96 & 1.71 & 1.63 & 45.73 \\
Total & 19.86 & 24.05 & 23.56 & 16.63 & 7.43 & 37.06 \\
Essential & 7.46 & 11.17 & 10.13 & 6.63 & 4.37 & 34.39 \\
\hline
\end{tabular}

1. On a moisture-free basis. The values are the average of two determinations.

$\mathrm{CV}=$ Coefficient of variability (sample standard deviation expressed as a percentage of the mean).

acids, including seven essential amino acids. The total amount of essential amino acids in these mushroom samples varied from 4.37 to $11.17 \mathrm{~g} / 100 \mathrm{~g}$ on a moisture-free basis. Similarly, there was a marked variation in total amino acids. Tryptophan was not determined, as it was destroyed in the acid hydrolysis. The results revealed that mushrooms are indeed a good source of essential amino acids, as these accounted for $40-50 \%$ of the amino acid contents. Soci et al. (1969) reported a mean value of $4.8 \%$ for essential amino acids, while Kruela et al. (1978) analysed 15 edible wild mushrooms and found an overall mean value of $5.3 \%$. Our data on the amino acid composition are in reasonable agreement with the findings of the above workers.

As a result of these studies, it was found that five edible mushrooms in Pakistan varied widely in their nutrient and heavy metal (essential and toxic) contents. They are a rich source of potential nutrients, especially protein, fibre, essential amino acids and essential metals such as $\mathrm{Cu}, \mathrm{Zn}, \mathrm{Fe}$ and $\mathrm{Mn}$.
Acknowledgements. We are grateful to Mr. Fazal Mahmood and Mr. Anwar Ahmad for technical assistance in these studics. We also wish to thank Ms. Anna Damström who revised the English of the manuscript.

\section{References}

AOAC 1984: Association of Official Analytical Chemists. Ed. 14. - Pp. 251-270 and 413-428. Washington, D.C.

Bano, Z., Srinivasan, K. \& Smrivirta, H. 1962: Amino acid composition of the protein from a mushroom. - Appl. Microbiol. 11:184-187.

Blackburn, S. 1968: Amino acid determination methods and techniques. - Pp. 31-64. Mercel Dakkor, N.Y.

Danielsson, L.G., Jagner, D., Josefson, M. \& Westerlund, S. 1981: Computerized potentiometric stripping analysis for determination of cadmium, lead, copper and zinc in biological materials. - Anal. Chim. Acta 127:147-158.

FAO 1972: Food composition tables for use. In: East Asia, Food Policy. - Pp. 41-46. Nutrition Division, Food and Agriculture Organization, Rome.

Food \& Nutrition Board 1974: Recommended dictary allowances. Ed. 8. - National Academy of Sciences, Washington, D.C. 
FAO/WHO Expert Committee on Food Additive 1972: Evaluation of certain food additives and contaminants, mercury, lead and cadmium. - Techn. Rep. Ser. World Health Org. 505:32.

Fritsche, G. 1978: Breeding work. In: Chang, S.T. \& Hayes, W.A. (eds.), The biology and cultivation of edible mushrooms. - Pp. 239-248. Academic Press, New York.

Genders, R. 1969: Mushroom growing for every one. Ed. 3. - Pp. 20-21. Faber and Faber, London.

Government of Pakistan 1979: Pakistan Standards Institute Publication. No. 221. - 192 pp. Islamabad.

Hinneri, S. 1975: Mineral elements of macrofungi in oak-rich forests of Lenholm Island, inner archipelago of SW Finland. - Ann. Bot. Fennici 12:135-140.

Kreula, M., Saarivirta, M. \& Karanko, S.L. 1976: On the composition of nutrients in wild and cultivated mushrooms. - Karstenia 16:10-14.

Kreula, M., Saarivirta, M. \& Karanko, S.L. 1978: Contents of nutrient and dietary fibre in wild and cultivated mushrooms. - Karstenia 18 (suppl.): 43-48.

Little, J.M. \& Hills, F.G. 1972: Statistical methods in agricultural research. - Pp. 27-36 and 49-58. Agric. Extension Univ, California Publ.

O'Dell, B.L., Deboland, A.R. \& Koirotyhann, S.R. 1972: Distribution of phytate and nutritionally important ele- ments among the morphological components of cereal grains. - J. Agric. Food. Chem. 20:718-720.

Sattar, A. \& Chaudry, M.A. 1978: Trace element contents of foods and their interrelationships with protein values in milled fractions of wheat and triticle. - Pakistan J. Biochem. 11:45-48.

Souci, S.W., Fachmann, W. \& Kraut, H. 1969: Die Zusammensetzung der Lebensmittel. II. - Pp. 1-4. Wissenschaftliche Verlagsgesellschaft, M.B.H., Stuttgart.

Stanton, R. 1984: The nutritional value of mushrooms. Mushrooms J. 133:27-29.

Zafar, S.I. 1986: Pakistan suited to mushroom cultivation. The Pakistan Times, August 22, 1986.

Zakhary, J.W., Abo-Bakr, T.M., El-Mahdy, A.R. \& ElTabery, S.A.M. 1983: Chemical composition of wild mushrooms collected from Alexandria, Egypt Food Chem. $11: 31-41$.

Zakhary, J.W., El-Mahdy, A.R., Abo-Bakr, T.M. \& ElTabey-Shehata, A.Am. 1984: Cultivation and chemical composition of the paddy straw mushroom. - Food Chem. $13: 265-276$.

Received on 16 November 1990 